REDIMAT

Journal of Research in Mathematics Education
Hipatia Press

www.hipatiapress.com

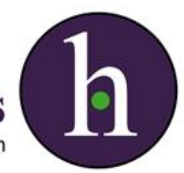

Instructions for authors, subscriptions and further details:

http://redimat.hipatiapress.com

\title{
Incentivizing with Bonus in a College Statistics Course
}

Victoria Ingalls ${ }^{1}$

1) Tiffin University

Date of publication: February $24^{\text {th }}, 2018$

Edition period: February 2018-June 2018

To cite this article: Ingalls, V. (2018). Incentivizing with bonus in a college statistics course. REDIMAT, 7(1), 93-103. doi:

http://dx.doi.org/10.17583/redimat.2018.2497

To link this article: http://dx.doi.org/10.17583/redimat.2018.2497

\section{PLEASE SCROLL DOWN FOR ARTICLE}

The terms and conditions of use are related to the Open Journal System and to Creative Commons Attribution License (CC-BY). 
REDIMAT, Vol. 7 No. 1 February 2018 pp. 93-103

\section{Incentivizing with Bonus in a College Statistics Course}

Victoria Ingalls

Tiffin University

(Received: 09 January 2017; Accepted: 04 December 2017; Published: 24 February 2018)

\section{Abstract}

Many studies have argued the negative effects of external rewards on internal motivation while others assert that external motivation does not necessarily undermine intrinsic motivation. At a private university, students were given the option to earn bonus points for achieving mastery in the online homew ork systems associated with Statistics and Pre-Calculus courses. The results showed a significant difference in online homework grades and final exam scores, dependent upon when the incentive was given. The findings of this research suggest that college students thrive when incentivized. When compared to the students who were not incentivized, the incentivized group had a statistically significantly higher mean for both online homework scores and final exam scores. Many of the incentivized students chose to take the opportunity to earn the bonus points to increase the final semester grade, which apparently also helped to increase the content knowledge necessary for the final exam.

Keywords: Bonus, Statistics, incentives 
REDIMAT, Vol. 7 No. 1 Febrero 2018 pp. 93-103

\title{
Incentivando con Bonos en un Curso de Estadística Universitario
}

\author{
Victoria Ingalls
}

Tiffin University

(Recibido: 09 Enero 2017; Aceptado: 04 Diciembre 2017; Publicado: 24 Febrero 2018)

\section{Resumen}

Muchos estudios han argumentado los efectos negativos de las recompensas externas en la motivación interna, mientras que otros afirman que la motivación externa no necesariamente socava la motivación intrínseca. En una universidad privada, se les dio a los estudiantes la opción de ganar puntos de bonificación por realizar correctamente las tareas de los cursos de Estadística y Pre-cálculo. Los resultados mostraron una diferencia significativa en las calificaciones de las tareas en línea y puntuaciones en los exámenes finales, dependiendo de cuándo se otorgó el incentivo. Los hallazgos de esta investigación sugieren que los estudiantes universitarios mejoran sus notas cuando se les incentiva. En comparación con los estudiantes que no fueron incentivados, el grupo incentivado tuvo una media estadísticamente significativamente mayor en las notas de las tareas en línea y las notas del examen final. Muchos de los estudiantes incentivados optaron por aprovechar la oportunidad de ganar puntos de bonificación para aumentar la calificación final del semestre, lo que aparentemente también ayudó a aumentar el conocimiento del contenido necesario para el examen final.

Palabras clave: Bonificaciones, Estadística, incentivos

2018 Hipatia Press

ISSN: $2014-3621$

DOI: $10.4471 /$ redimat.2018.2497 
$\mathrm{M}$ any studies have argued the negative effects of external rewards on internal motivation (Akin-Little, Eckert, Lovett, \& Little, 2004; Harlow, Harlow, \& Meyer, 1950; Leper, 1983; Rummell \& Fielding, 1988), while others assert that external motivation does not necessarily undermine intrinsic motivation (Pittman, Boggiano, \& Ruble, 1983; Vansteenkiste, Lens, \& Deci, 2006), including the Cameron, Banko, and Pierce (2001) synthesis of 145 motivational studies. The current literature further refines the external reward into that which is either coerced and controlling (Rassouli, 2012) with words such as "should," "ought," and "have to" (Vansteenkiste et al., 2006) or a reward that that is brought to fruition by autonomous motivation which is optional, volitional, and personally relevant (Black \& Deci, 2000; Vansteenkiste et al., 2006; Vasteenkiste, Lens, DeWitte, DeWitte, \& Deci, 2004; Rassouli, 2012). Behavioral theorists assert that when engagement is autonomous and voluntary, the extrinsic rewards enhance learning without ill effects (Rassouli, 2012). Autonomy-supportive contexts allow instructors to "empathize with the learner's perspective, allow opportunities for selfinitiation and choice, ... refrain from the use of pressures and contingencies to motivate behavior..." (Deci et. al, 1994, p.21). In such a context, rewards for low-interest activities may serve to increase interest and therefore also increase internal motivations (Akin-Little et al., 1986; Cameron et al., 2001). Despite a rise in concern of school psychologists over classroom reward contingency systems during the mid to late 1990's (Deci, Koestner, \& Ryan, 1999a, 1999b, 2001; Kohn, 1993, 1996), the practice of rewarding students continues with vigor. Academic reinforcements are often given for academic output (Akin-Little et al., 2004) where the creation of "appropriate situation interest enhances students' meaningful participation in classroom activities with long-lasting effects" (Rassouli, 2012, p. 87). Some studies have also determined that external rewards can be effective tools for enhancing learners' motivation for learning (Akin-Little et al., 2004; Cameron, \& Pierce, 1994; Rassouli, 2012). Some researchers have found that when motivation is increased, class participation and persistence over the short term are higher than those with a no-goal condition (Jung, Leung, \& Miller, 2016; Miller \& Mallott, 1997; Vansteenkiste et al., 2006). Experimental researchers are hopeful that mere mention of the relationship of learning tasks to intrinsic goals tends to be beneficial to student learning, since knowing the 
relevance of an activity can be a source of motivation (Vansteenkiste et al., 2006).

More specifically, the use of incentives as a reward structure contingent on classroom performance has shown to produce greater degrees of adherence to performance standards than behaviors without incentives (Bailey, Rosnethal, \& Yoon, 2016; DeVahl, King, \& Williamson, 2005; Nonis, Ford, Logan, \& Hudson, 1996; Miller \& Mallott, 1997; Rousu et al, 2015; Tudor \& Bastow, 1991). Bailey, Rosnethal, \& Yoon (2016) suggest a nuanced relationship "between grades, incentives, and subsequent academic outcomes" (p. 1548). One such form of an external reward to link those concepts is the ubiquitous bonus point pervasive in all levels of education. While the simplistic bonus score scheme can supplement any classroom activity to generate and embed intrinsic interest (Rassouli, 2012), it also informs students of a point contingency on some post-test performance (Miller \& Mallott, 1997) toward improving course grades (DeVahl et al., 2005) and the ultimate goal of mastering the learning materials (Rassouli, 2012). The application of the bonus point structure as implied by many studies (Deci, 1971; DeVahl et al., 2005; Miller \& Mallott, 1997; Rassouli, 2012) is the core of the study at hand. In short, the impetus was to test the theory set forth by Rassouli (2012) which suggests that academic incentives "may in effect ignite internal motivation and therefore reinforce learners' participation and deep learning" (p.87).

Bonus points were used as the motivating factor in the current study in a sample taken from a small private Midwestern university. Here, three years of students in Statistics and Pre-Calculus were given the option to earn 5 bonus points awarded at the end of the semester for anyone who had a $100 \%$ on all of the online homework for the semester. In the first year, no bonus incentive was given. In the second year, incentives were optioned to students during the last 2 weeks of the semester, while in the third year they were given the option on the first day of class. The ex post facto observational design categorized my 203 students as either early incentivized, late incentivized, or not incentivized groups of students, then studied the means of their online homework grades and final exam scores. Further study into these groupings analyzed the potential correlation between final homework grade and final exam grade and the relationship status of when the students were incentivized and whether or not they completed the homework to the stated $100 \%$ level. 


\section{Methodology}

\section{Participants}

The sample was comprised of 215 undergraduate students from Pre-Calculus $(n=24)$ and Statistics $(n=191)$ classes at a small private university who complete their assignments with the Pearson MyStatLab online homework system whose points account for approximately $25 \%$ of the semester course grade. Most of the students held sophomore status at the time of the class. After the course grades were turned in to the registrar, the students were first separated in to groups who earned the $100 \%$ on the online homework ( $\mathrm{n}=$ 66) or those that did not earn the $100 \%$ on the online homework $(n=149)$. The groups were then further refined into categories based upon when and if they were incentivized. The early incentives group $(n=60)$ roster derived from the fall 2016 roster and were those students who were told of the 5 point bonus incentive for earning a $100 \%$ on the online homework provision on the first day of the semester. The late incentives group $(n=74)$ were the students from the respective fall and spring semesters of the 2015-2016 academic year; they were given the bonus incentive during the last two weeks of the semester. The initial group of students were those who were not provided any incentive to complete the semester, now termed as the no-incentives group $(n=71)$, from the spring 2015 semester. Any numerical discrepancies from the total sample to the individual groupings were due to students either notcompleting or officially dropping the class.

\section{Analysis}

EXCEL was used to compute the statistical analysis of the first five research questions. The first question concerned finding a difference in the mean online homework score for those students who completed the performance criterion of earning a $100 \%$ on the online homework. The second point of research was similar in its relative question, but with respect to the final exam score: question two searched for a difference in the mean final exam score for those who did and those who did not meet the performance standard of earning a $100 \%$ on the online homework. Questions three and four parsed out more details than the previous two questions as the groups were sub-divided by the timeliness of the incentive. More specifically, the third research 
question asked if there was a difference in the mean online homework scores for the early, late and no- incentive groups. The fourth research question asked if there was a difference in the mean final exam scores for the early, late and no-incentive groups. Question five sought out any relational value of online homework grade (regardless of time of incentive) to final exam score and question six pursued a relationship between when the incentive of 5 bonus points was provided (i.e. early, late, no-incentive) and whether the students completed the $100 \%$ criterion standard for the homework. Specific statistical analyses were independent $t$ tests assuming unequal variances (questions 1 and 2), one-way ANOVA (questions 3 and 4), correlation (question 5), and Chi Square test for independence (question 6).

\section{Results}

The results of the statistical analyses are a product of identical online homework activities taught by the same professor in the respective PreCalculus and Statistics classes. The rigor, teaching methods, learning techniques, procedures for collecting data were identical. The activities were complementary to student learning and assessment (Deci, 1971).

For the first research question concerning the mean differences in the online homework grades for the incentive and no-incentive group, the results of the independent $t$ test assuming unequal variances were significant. There were 65 observations in the incentivized student group, compared to 137 for the no-incentive groups. Their respective mean scores were 86.7 and 79.2 with $\mathrm{t}(171)=3.954, \mathrm{p}<.001$. The second research question asked about the same two groups of students, but identified the means of the final exam scores. Again, an independent t test assuming unequal variances showed statistically significant results with $\mathrm{t}(178)=4.271, \mathrm{p}<.001$. The sample means for the final exams were 88.3 for the incentivized group and 79.2 for the non-incentivized group. The Cohen's $d$ value for effect size was .56 .

The third and fourth tests were each run as one-way ANOVAs to answer the questions about the differences in the mean online homework scores and the mean final exam scores, respectively. These two tests separated the students by when the incentive was given to the class. The fall 2016 students were told of the contingency-based reward on the first day of class, with frequent reminders of the standard and dividend. The fall and spring semester students of 2015-2016 were allotted the 5 bonus point incentive 2 weeks prior 
to the semester's end. For the spring 2015, no incentive was given. The results of the online homework grade comparison was $\mathrm{F}(2,213)=3.612$, $\mathrm{p}<$ .05. However, a post hoc Tukey's test demonstrated no difference between the early and late incentivized groups $(p=.70)$, and no difference between early and no-incentives $(\mathrm{p}=.42)$. A significant difference exists between the late and no-incentive group ( $\mathrm{p}=.02)$. The Cohen's $d$ value for effect size was .59 .

Similar results were found in the overall groupings when compared for final exam scores. Here, the respective 213 students' results were $\mathrm{F}(2,211)=$ $3.166, \mathrm{p}<.05$. Recognizing the significant differences, the post hoc test demonstrated a significant difference between the early and late incentivized groups $(\mathrm{p}=.03)$, though there was no difference between early and noincentives $(\mathrm{p}=.42)$. Likewise, there was no difference between the late and no-incentive group ( $\mathrm{p}=.34)$.

With respect to the correlation between online homework scores and final exam scores, the $\mathrm{r}$ value was .258 , showing a weak positive relationship. The r square value was approximately .07 , or only $7 \%$ of the variation in final exam scores can be explained by the variation in the online homework score. Nonetheless, the results were again significant with $\mathrm{p}<.001$. The Cohen's $d$ value for effect size was .53. Lastly, in the chi square test for independence, the results were $\chi^{2}(2)=50.549, \mathrm{p}<.0001$. The Cramer's V test for association also showed a significant value with $\mathrm{p}<.0001$. There is therefore a relationship applicable to the population with respect to the qualitative variables of time of incentive and yes/no status for meeting the bonus quality standard.

\section{Discussion}

The findings of this research suggest that college students thrive when incentivized. When compared to the students who were not incentivized, the incentivized group had a statistically significantly higher mean for both online homework scores and final exam scores. Many of the incentivized students chose to take the opportunity to earn the bonus points to increase the final semester grade, which apparently also helped to increase the content knowledge necessary for the final exam. Though adding to the current body of literature, this research is specific to the college mathematics student. Nonetheless, the results adhere with the prior studies that suggested that 
extrinsic rewards do no harm to intrinsic motivations (Black \& Deci, 2000; Cameron et al., 2001; Pittman, Boggiano, \& Ruble, 1983; Rassouli, 2012; Vansteenkiste et al., 2004; Vansteenkiste et al., 2006) as well as those that take their discussion to state that autonomous-supportive rewards allow the increase in interest and therefore positively impact learning.

Moreover, when re-grouped to demonstrate the timeliness of the 5 bonus point for earning a $100 \%$ on the online homework incentive, the results once again showed a significant difference in the means for the online homework. Although the early and late homework means were not necessarily significant from the no-incentives group in the post hoc tests, both of the incentivized groups had much greater numbers participating in achieving the standard than those who were not offered the reward. The early incentives group from the fall 2016 semester had 25 of 60 (about 42\%) students earn the standard; when backtracked by week for the early incentivized group, the data shows that 13 of 60 (about 22\%) students kept the $100 \%$ online homework score throughout the entire semester. (Unfortunately, the nature of this ex post facto study did not allow for re-counting in the semesters prior to fall 2016.) By comparison, the late incentives group had 26 of 72 (about 36\%) students earn the $100 \%$ on the online homework, and only 5 of 85 (about 6\%) students from the late incentives group in the 2015 spring semester earned the top grade. The results did demonstrate a significant difference in the means for the late and no-incentive groups. The nature of the one way ANOVA focused solely in the factor of the timeliness of the incentive being given, apparently serving as strong motivator to enhance final course grades closest to the end of the semester rather than earlier on in the course or not at all.

The ANOVA analysis of final exam scores appears to support the theories concerning deeper learning and possibly classroom engagement, as reported by Deci (1971). That is, since they did the work based on the incentive, the externally motivated students were better able to comprehend what was happening in class thereby making them more aware of the knowledge gaps that they need to close. This result provides further evidence of the DeVahl et al. (2005) claims concerning academic incentives and student behaviors. The students tried harder based upon the incentive and were able to form deeper connections to the class content, thereby improving their final exam scores as compared to the late and no-incentive groups. The early and late incentives groups were overt in their engagement of the behaviors and 
knowledge embedded in the programmed instruction (Miller \& Mallott, 1997).

Finally, when the relationships are examined, both the quantitative and qualitative questions again proved significant. Each class had the same online homework system with the same questions, taught by the same professor with the same lesson plans: the external motivator of 5 bonus points was the only measureable difference in the classes by semester. Although there is only a weak positive correlation between online homework scores and final exam grades, the results remain significant at the 5\% level. However, the correlational value of $\mathrm{r}=.258$ explains only $7 \%$ of the variation in the dependent variable exam results. One explanation is that the discriminating variable of time of incentive could have affected this test in a negative manner if students were cramming rather than understanding the content at a deeper level. Despite the coefficient of determination and the timeliness of the incentive, the results demonstrated that there is a relationship between earning the criterion standard of $100 \%$ (i.e. motivation) and exam score.

In future semesters, I will certainly be providing the incentive early in in the semester to provide them with the opportunity to develop interest and transform the external reward into internal motivation and autonomous goalsetting. Similar to Rassouli's (2012) findings, it will continue to be essential to keep the incentive in the autonomous-support category of external motivation so that students do not feel coerced but rather supported with the external rewards closely aligned with the goal of learning. In conclusion, regardless of the criticisms on the effects of external rewards' negative influence in educational settings (Akin-Little et al., 2004) these results show a practice worth continuing.

\section{Limitations}

Although the results in this study are promising, some general limitations and suggestions for future study exist. For instance, the 215 students involved in this study represent only the population of students in private universities whose ACT test scores approximate the national average that mimics the national average. Additionally, although the results demonstrated a medium effect size, this may be considered less impactful to the general population. Finally, as is the case with most research, a longer study involving more 
students and a different collection of instructors could possibly change the results.

\section{References}

Akin-Little, K., Eckert, T., Lovett, B., \& Little, S. (2004). Extrinsic reinforcement in the classroom: Bribery or best practice. School Psychology Review, 33(3), 344-362.

Bailey, M., Rosenthal, J., \& Yoon, A. (2016). Grades and incentives:

Assessing completing grade point average measures and postgraduate outcomes. Studies in Higher Education, 41(9), 1548-1562. doi: https://doi.org/10.1080/03075079.2014.982528

Bandura, A. (1986). Social foundations of thought and action: A social cognitive theory. Englewood Cliffs, NJ: Prentice Hall.

Black, A., \& Deci, E. (2000).The effects of instructors' autonomy support and students' autonomous motivation on learning organic chemistry: A self-determination theory perspective. Science Education, 84, 740756. doi: 10.1002/1098-237X(200011)84:6<740::AID-

SCE4>3.0.CO;2-3

Bransford, J.D., Brown, A.L., \& Cocking, R.R. (Eds.). (2000). How people learn: Brain, mind, experience, and school. Washington, D.C.: National Academy Press.

Cameron, J., Banko, K., \& Pierce, D. (2001). Pervasive negative effects of rewards on intrinsic motivation. The Behavior Analyst, 24 (1), 1-44. doi: https://doi.org/10.1007/BF03392017

Cameron, J. \& Pierce, D. (1994). Reinforcement, reward, and intrinsic motivation: a meta-analysis. Review of Educational Research, 64, 363-423. doi: https://doi.org/10.3102/00346543064003363

Deci, E. (1971). Effects of externally mediated rewards on intrinsic motivation. Journal of Personality and Social Psychology, 18(1), 105-115. doi: http://dx.doi.org/10.1037/h0030644

Deci, E. (1975). Intrinsic motivations. New York, NY: Plenum Press.

Deci, E., Eghrari, H., Patrick, B., \& Leone, D. (1994). Facilitating internalization: The self-determining perspective. Journal of Personality, 62, 119-142. doi: 10.1111/j.1467-6494.1994.tb00797.x 
Deci, E., Koestner, R., \& Ryan, R. (1999a). A meta-analytic review of experiments examining the effects of extrinsic rewards on intrinsic motivation. Psychological Bulletin, 125, 627-668.

Deci, E., Koestner, R., \& Ryan, R. (1999b). The undermining effect is a reality after all- extrinsic rewards, task interest, and selfdetermination. Psychological Bulletin, 125, 692-700.

Deci, E., Koestner, R., \& Ryan, R. (2001). Extrinsic rewards and intrinsic motivation in education: Reconsidered once again. Review of Educational Research, 71, 1-27. doi: https://doi.org/10.3102/00346543071001001

DeVahl, J., King, R., \& Williamson, J. (2005). Academic incentives for students can increase participation in and effectiveness of a physical education program. Journal of American College Health. 53(6), 295298.doi: https://doi.org/10.3200/JACH.53.6.295-298

Harlow, H., Harlow, M. \& Meyer, D. (1950). Learning motivated by manipulative drive. Journal of Experimental Psychology, 40, 228234.doi: http://dx.doi.org/10.1037/h0056906

Jung, Y., Leung, A., \& Miller, J. (2016). Do smart students study harder? An investigation of efficient effort among undergraduate university students. Journal of Economics and Economics Education, 17(1), 2538.

Kohn, A. (1993). Punished by rewards: The trouble with gold stars, incentive plans, $A$ 's, praise, and other bribes. Boston: HoughtonMifflin.

Kohn, A. (1996). By all available means: Cameron and Pierce's defense of extrinsic motivators. Review of Educational Research, 66, 1-3. doi: https://doi.org/10.3102/00346543066001001

Leper, M. (1983). Extrinsic reward and intrinsic motivations: Implications for the classroom. In J.M. Levine \& M.C. Wang (Eds.), Teacher and student perceptions: Implications for learning (pp. 281-317). Hillsdale, NJ: Erlbaum.

Miller, M., \& Mallott, R. (1997). The importance of overt responding in programmed instruction even with added incentives for learning. Journal of Behavioral Education, 7(4), 497-503. doi: https://doi.org/10.1023/A:1022811503326

Nonis, S., Ford, C., Logan, L., \& Hudson, G. (1996). College student's blood donation behavior: relationship to demographics, perceived 
risks, and incentives. Health Marketing Quarterly, 13(4), 33. doi: https://doi.org/10.1300/J026v13n04_04

Pittman, T., Boggiano, A. \& Ruble, D. (1983). Intrinsic and extrinsic motivational orientations: Limiting conditions on the undermining and enhancing effects of reward on intrinsic motivation. In J.M. Levine \& M.C. Wang (Eds.), Teacher and student perceptions: Implications for learning (pp. 319-340). Hillsdale, NJ: Erlbaum.

Rassouli, A. (2012). Engagement in classroom learning: Creating temporal participation incentives for extrinsically motivated students through bonus credits. Journal of Education for Business, 87, 86-93.doi: https://doi.org/10.1080/08832323.2011.570808

Rousu, M., Corrigan, J., Harris, D., Hayter, J.,Houser, S., Lafrancois, B., Onafowora, O., Colson, G., Hoffer, A. (2015). Do monetary incentives matter in classroom experiments? Effects on course performance. Journal of Economics Education, 46(4), 341-349.doi: https://doi.org/10.1080/00220485.2015.1071214

Rummell, A. \& Fielding, R. (1988). Cognitive evaluation theory: a metaanalysis review of the literature. Social Behavior and Personality, 16, 147-164.doi: https://doi.org/10.2224/sbp.1988.16.2.147

Tudor, R.M., \& Bostow, D.E. (1991). Computer-programmed instruction: The relation required interaction to practical application. Journal of Applied Behavior Analysis, 24, 361-368.doi: 10.1901/jaba.1991.24361

Vasteenkiste, M., Lens, W., Deci, E. (2006). Intrinsic versus extrinsic goal contents in self-determination theory: Another look at the quality of academic motivation. Educational Psychologist, 41(1), 19-31.doi: https://doi.org/10.1207/s15326985ep4101_4

Vasteenkiste, M., Lens, W., DeWitte, S., DeWitte, H., Deci, E. (2004).The "why and "why not" of job search behavior: Their relation to job searching, unemployment experience and well-being. European Journal of Social Psychology, 34, 346-363.doi: 10.1002/ejsp.202 
Victoria Ingalls is associated professor in the Department of Mathematics, at Tiffin University, USA.

Contact Address: Direct correspondence concerning this article, should be addressed to the author. Postal address: 155 Miami St, Tiffin, OH 44883 Email: ingallsv@tiffin.edu 